\title{
Predicting biomass of beaver food from willow stem diameters
}

\author{
BRUCE W. BAKER AND BRIAN S. CADE
}

Authors are wildlife biologist and biological statistician, respectively, Midcontinent Ecological Science Center, National Biological Senice, USDI, 45I2 McMurny Ave., Fort Collins, Colo. 80525-3400.

\begin{abstract}
Beaver (Castor canadensis Kuhl) and willow (Salix spp.) are important components of riparian restoration on degraded western rangelands. Land managers need quantitative information to evaluate carrying capacity and potential habitat quality for beavers in riparian-willow systems. Our objectives were to determine the best model to predict biomass components of coyote willow (S. exigua Nuttall) from basal stem diameters and compare model predictions to diameter class averages. The study was conducted in a shrub-steppe ecosystem of northwestern Colorado. We estimated oven-dried weights of annual and total beaver food and total live biomass by diameter class from a sample of 160 willow stems. Several variants of a logistic function were fit with nonlinear least squares regression to select a model that best predicted mean biomass by stem diameter. A four-parameter logistic model provided the best fit for all 3 stem components. Predicted biomass estimates of beaver food and total live biomass had smaller standard errors than sample means for all 10 stem diameter class midpoints. Percentage of stem weight that was beaver food varied from $93.6 \%$ for the smallest stems to $12.2 \%$ for the largest. We concluded that the logistic model provided reliable estimates of beaver food biomass and could be used with food consunption rates and stem density data to evaluate carrying capacity for beaver or test assumptions in the beaver habitat suitability index model.
\end{abstract}

Key Words: Castor canadensis, coyote willow, Salix exigua, logistic model, nonlinear least squares regression.

As rangeland reform accelerates the pace of riparian restoration, land managers will need better data on the relations between beaver (Castor canadensis Kuhl) and willow (Salix spp.). Beavers serve as a keystone species by altering both landscape form and function. Beaver dams alter watersheds by trapping sediment, storing water, modifying flow regimes, and expanding the extent and dynamics of riparian zones (Naiman et al. 1988). Dams also increase duration of moist soil and provide exposed sediment for willow establishment. Stem cutting by beavers,

Authors wish to thank Jay Graham and Dave Hawksworth for field assistance, David Anderson and Tom Stanley for statustical assistance, and John Basey, Wayne Leininger, and John Oldemeyer for rev sewing the manuscript. Manuscript accepted 11 Nov. 1994. which normally occurs when willows are dormant, promotes suckering and rapid growth (Kindschy 1989). These characteristics have prompted land managers to use both beaver and willow as tools for riparian restoration (Apple et al. 1985, Conroy and Svejcar 1991). However, in high elevation shrub-steppe ecosystems, willows may be the only winter food and limit beaver populations (pers. obs., B.W. Baker). Because of the fear that beavers may overharvest willows, many managers are reluctant to include beavers in restoration efforts until abundance of willows is sufficient to support a beaver population.

Coyote (also known as sandbar) willow (S. exigua Nuttall) is a widespread riparian species on western rangelands (Dorn 1977. Brunsfeld et al. 1991). Although much of its former habitat has been degraded, it is a key component of healthy riparian ecosystems and is vital to their restoration. Willows are important to riparian function because they provide structure that traps sediment, roots that bind the soil and reduce erosion, shade that cools streams, and food and cover that maintains regional biodiversity. Past research on beaver food production by woody plants is limited and was conducted in forested riparian habitats, especially aspen (Populus tremuloides Michaux). Belovsky (1984) and Fryxell and Doucet (1991) used stem diameter to predict ovendry weights of summer beaver food (leaves, bark, and twigs) produced by several species of eastern hardwoods in their studies of beaver foraging strategies. Aldous (1938) and O'Brien (1938) peeled the bark and leaves from aspen to estimate beaver food as a function of stump diameter. Pearson (1977) calculated the amount of willow used as beaver food by multiplying the biomass estimates of Aldous (1938) by 3 to account for vigorous sprouting of willow (Hall 1960). MacDonald (1956) estimated air-dried biomass (pers. comm., D. MacDonald, U.S.F.W.S., Washington, D.C.) of beaver food for 3 diameter classes of willow stems. He used these, in combination with biomass estimates of aspen from Aldous (1938), to evaluate beaver carrying capacity in a mountain aspen-willow riparian community in northern Colorado.

Several studies have shown that biomass of browse can be predicted from stem dimensions, including diameter (Telfer 1969 , Brown 1976, Oldemeyer 1982, Ruyle et al. 1983, Alaback 1986a, Roundy et al. 1989). MacCracken and Van Ballenberghe (1993) used data-splitting procedures to validate regression models that predicted biomass of moose (Alces alces gigas Miller) browse [willow, alder (Alnus spp.)] from stem diameter and other metrics. 
Allen (1983) developed a habitat suitability index (HSI) model for beaver that uses canopy cover and height of hydrophytic woody vegetation (e.g., willow) to rate habitat quality for beaver. This model assumes cover and height are directly correlated to winter food availability, but offers no empirical data for support. Before this assumption can be tested, reliable estimates of beaver food production must be available. The purpose of our study was to predict biomass of beaver food produced by coyote willow. Specifically, we asked the following questions: 1) How much biomass is produced by willow stems of various diameters? and 2) How well do statistical models, such as the logistic function, predict these relationships?

\section{Methods}

\section{Study Area}

Data were collected from northwestern Colorado as part of a larger study to evaluate interaction among cattle, beaver, vegetation, and birds in the Douglas Creek watershed, Rio Blanco County (Baker et al. 1992). We collected coyote willow samples from elevations of 1,900 to 2,050 m along East Douglas Creek, a highly eroded drainage where over 10 years of cooperative restoration by the Bureau of Land Management (BLM) and the permittee has increased cover and extent of willow, widened the floodplain, and aggraded the channel (pers. comm., E. Hollowed, BLM, Meeker, Colo. and unpubl. data, B.W. Baker). This channel cuts through the alluvial deposition of the drainage basin that supports dense stands of big sagebrush [Artemesia tridentata tridentata (Nuttall)] and black greasewood [Sarcobatus vermiculatus (Hooker) Torrey] contained by steep ridges of pinyon-juniper [Pinus edulis Engelmann-Juniperus asteosperma (Torrey) Little] and mountain shrub (Vories 1974). Coyote willow was the only willow present and dominated the riparian channel (Baker et al. 1992). Cattle grazed the allotment spring-fall and mule deer [Odocoileus hemionus (Rafinesque)] and elk (Cervus elaphus L.) were present all year. Beaver densities increased dramatically during restoration, from scattered colonies to continuous occupation, resulting in 34 winter territories and 334 dams in the $23-\mathrm{km}$ section of stream studied (unpub. rep. 1990 and pers. comm., E. Hollowed, BLM, Meeker, Colo.).

\section{Willow Sampling}

We estimated biomass components from a random sample of 160 coyote willow stems collected from East Douglas Creek. Willows were cut and peeled in October and November 1991, following leaf fall. We cut stems at $10 \mathrm{~cm}$ above ground, the approximate height cut by beavers on the study area. Collected stems were grouped into 10 classes based on their diameter (mm) at the cut: $0-2.5,2.5-5.0,5-10,10-15,15-20,20-25,25-$ $30,30-35,35-40$, and 40-60. Interval widths were less for the first 2 classes to capture more detail at smaller diameters (whips), which dominated upper East Douglas Creek. Stems between 40 and $60 \mathrm{~mm}$ were grouped into 1 class for analysis because few occurred at these larger diameters. We estimated age by counting annual growth rings, using multiple readings of $>1$ radii, a hand lens, observing the entire ring circumference, or diagonal cuts to ensure false rings were not counted and actual rings were not missed. Stems were recorded as either browsed by ungulates or cut by beaver if 1 or more branches on a stem had been damaged.
Willow samples were oven-dried at $65^{\circ} \mathrm{C}$ until weights of the larger stems stabilized, which took several days.

We estimated oven-dried biomass of 4 stem components: annual food, total food, total live, and dead. Before peeling, we first separated current annual growth and dead material from the main stem. Following O'Brien (1938) and MacDonald (1956), we defined beaver food (both current annual and previous years' growth) as entire twigs $<3 \mathrm{~mm}$ in diameter and peeled bark (bark, phloem, and cambium layers) from the remaining stem. Peeled stems $>3 \mathrm{~mm}$ in diameter (woody part of stem often used by beaver to build dams) were weighed separately and added to total food to estimate total live biomass. Total food and total live biomass were computed by summing values for current annual and previous years' growth. Dead branches, which included only those still attached when collected, were also oven-dried and weighed.

\section{Data Analysis}

We first estimated sample means and standard errors of biomass for each of the 10 stem diameter classes. In addition, we plotted observations of annual food, total food, and total live biomass of willow by diameter class midpoint. These plots indicated that a logistic function could be used to model biomass as a function of diameter class. Several variants of a logistic function were fit with nonlinear least squares regression (Bates and Watts 1988). We selected the best model based on smallest Akaike Information Criteria (AIC) statistics, which provides a parsimonious choice of parameters balancing model bias and fit (Sakamoto et al. 1986), residual plots, an F-test for lack-of-fit (Bates and Watts 1988), and standard errors of predicted biomass compared to the sample estimates at each diameter midpoint. An acceptable model had predicted means from the nonlinear model and sample class means within 2 standard errors of each other at all stem diameters. The following models were considered:

$$
\begin{aligned}
& Y=\frac{\beta_{0}}{1+\mathrm{e}^{\left(\beta_{1}-\beta_{2} \mathrm{n}\right.}}, \\
& Y=\frac{\beta_{0}}{1+\mathrm{e}^{\left(\beta_{1}-\beta_{2} \ln x\right)}}, \text { and } \\
& Y=\frac{\beta_{0}}{1+\mathrm{e}^{\left(\beta_{1}-\beta_{2} \ln x \cdot \dot{\beta}_{3}(\ln x)^{2}\right)}}
\end{aligned}
$$

where $Y$ is biomass, $x$ is diameter class midpoint, and $\beta_{0}, \beta_{1}, \beta_{2}$. and $\beta_{3}$ are parameters to estimate.

We used the Gauss-Newton procedure in SAS (SAS Institute Inc. 1987) to estimate model parameters and to predict means and standard errors at diameter midpoints. A derivative-free quasiNewton procedure in SYSTAT (Wilkinson 1990) was used to explore initial model fits and to obtain starting parameter estimates. Because variance appeared to increase as a multiplicative function of diameter class midpoint, we modeled error variance of biomass as: $\sigma_{1}^{2}=\sigma^{2} *\left(x_{i}\right)^{\mathrm{c}}$, where $x_{i}$ is diameter class midpoint for the $i^{\text {th }}$ class. We estimated $\mathrm{c}$ from slopes of a linear regression $(\mathrm{n}=10)$ of $\ln \left(\mathrm{s}_{\mathrm{i}}^{2}\right)$ on $\ln \left(x_{i}\right)$ (McClure and Czaplewski 1987 , Parresol 1993). Residual plots showed linear regression provided a good fit on the In scale. Slope coefficients were rounded to nearest 0.5 to use as exponents for weights, $1 /$ (diameter class midpoint $)^{c}$, in the nonlinear estimation procedures. 
Table 1. Parameter estimates and asymptotic standard errors for nonlinear least squares regression models of annual and total beaver food and total live biomass as a function of willow stem diameter class. Regression models are of the form: $Y=\beta_{0} /\left(1+\exp \left(B_{1}-\beta_{2} \ln x-B_{3}(\ln x)^{2}\right)\right)$, where $Y$ is biomass and $x$ is willow stem diameter class. Weights corresponding to the reciprocal of (willow diameter class) ${ }^{\mathrm{c}}$ were used to estimate the nonlinear regression model with a Gauss-New ton procedure (SAS Institute Ine 1987). Mean square error (MSE) has 156 df for all biomass components. All regression models were significant at $P \leq 0.0001$.

\begin{tabular}{lrccccccc}
\hline \hline $\begin{array}{l}\text { Biomass } \\
\text { component }\end{array}$ & $\mathrm{b}_{0}$ & $\mathrm{~b}_{1}$ & $\mathrm{~b}_{2}$ & $\mathrm{~b}_{3}$ & $\mathrm{MSE}$ & $\mathrm{c}$ & $\mathrm{F}$ & Lack-of-fit \\
\hline Annual food & $90.75 \pm 62.91$ & $6.05 \pm 0.75$ & $0.90 \pm 0.22$ & $0.16 \pm 0.08$ & 0.0057 & 3.0 & 1.522 & 0.178 \\
Total food & $154.50 \pm 21.16$ & $6.59 \pm 0.19$ & $0.77 \pm 0.20$ & $0.43 \pm 0.07$ & 0.0026 & 4.0 & 0.613 & 0.719 \\
Total live & $959.57 \pm 130.69$ & $8.59 \pm 0.22$ & $1.46 \pm 0.21$ & $0.34 \pm 0.06$ & 0.0059 & 4.5 & 0.694 & 0.655 \\
\hline
\end{tabular}

\section{Results and Discussion}

\section{Model Performance}

The four-parameter logistic model (3) had the smallest AIC values and provided the best fit to biomass for all 3 stem components (Table 1, Fig. 1a-c). Lack-of-fit tests were highly nonsignificant for all models, although less so for annual food (Table 1). Standard errors around biomass predictions from nonlinear models overlapped (indicating good fit) and were smaller (indicating better precision) than standard errors around estimated sample means for all 10 diameter class midpoints (Table 2). The ratio of the variances between larger and smaller diameter classes was greatest for total live biomass and least for annual food, as indicated by exponents for variance weights ("c" in Table 1) and plots (Fig. 1a-c). These results are consistent with Marshall et al. (1990), who found that $\log -\log$, multiple regression models were good predictors of browse biomass of willows.

The fact that biomass of beaver food followed a logistic pattern of increase with increasing stem diameter is not unexpected. Stem growth generally begins slowly as resources are put into root development, accelerates rapidly until full maturity is reached, and stabilizes or declines during senescence (Shepperd and Smith 1993). Alaback (1986b) found above-ground biomass increased exponentially, relative to basal stem diameter, for 3 species of forest understory shrubs; although in contrast to our results, his curves did not level-off at larger stem diameters. The logistic pattern was especially obvious in our data for total food (Fig. 1b). Relative biomass increased gradually until the third class (midpoint $=7.5 \mathrm{~mm}$ ), when the average age was 2.3 years (Table 3). At this point, the rate (slope of regression line on Fig. lb) increased and remained high until midpoint $27.5 \mathrm{~mm}$. In the largest 4 classes, biomass of total beaver food did not increase in proportion to stem diameter. Stems in larger classes were mostly $6-7$ years old (Table 3 ), except a few older stems ( 1 each at 10 , 11 , and 12 years) in the largest class. Amount of beaver food on a stem was relatively constant for mature willows, despite differences in stem diameter (Tables 2 and 3, Fig. 1B). We speculate this variation in size of older, similar-age stems may be due to differences in competition for light and nutrients resulting from expansion of the willow community following its release from livestock grazing. Alaback (1986b) found that shrubs growing in the open put more energy into stem development relative to those growing under closed canopies, where competition for light resulted in greater biomass of leaves relative to stems.

\section{Biomass Estimates}

Percentage of stem weight that was beaver food varied from $93.6 \%$ for whips $(0.0-2.5 \mathrm{~mm})$ to $12.2 \%$ for the largest class
$(40.0-60.0 \mathrm{~mm})$ (Table 3). Although whips were small enough to be entirely consumed by beaver, we found many of their tips were dead, which accounted for an average of $6.4 \%$ of their biomass (Table 3 ). The percentage of each stem that was dead varied greatly, depending on how much had been broken off by wind, flooding, or animal movements and by differences in growth conditions. The largest stems were often decadent and contained over $25 \%$ dead material, but still produced the most annual and total beaver food (Tables 2 and 3).

MacDonald (1956) sampled 25 willow stems (species not identified) to estimate biomass of beaver food from 3 diameter classes. Mean biomass was 7.6, 33.3, and $89.7 \mathrm{~g}$ for stem diameter classes of $<6.4,6.4-12.8$, and $>12.8 \mathrm{~mm}$, respectively. He multiplied biomass estimates by estimates of stem density within a diameter class to conclude that 1.6 ha of aspen or 4.9 ha of willow (or less in combination) was required to support a typical colony of 6 beavers on a sustained-yield basis. However, because he reported air-dried weights and studied different woody species, his results are not directly comparable to ours. Surprisingly, Belovskys' (1984) estimates of annual beaver food were similar to ours, even though his samples included leaves and were dissimilar to willow

Table 2. Comparison of oven-dried biomass estimates $(\vec{x} \pm S E)$ of beaver food from coyote willow stems using a logistic model (top row) and the sample data (bottom row) by diameter class.

\begin{tabular}{|c|c|c|c|c|}
\hline $\begin{array}{l}\text { Diameter } \\
\text { class } \\
\text { midpoint }\end{array}$ & $\mathrm{n}$ & $\begin{array}{l}\text { Annual } \\
\text { food }\end{array}$ & $\begin{array}{l}\text { Total } \\
\text { food }\end{array}$ & $\begin{array}{l}\text { Total } \\
\text { live }\end{array}$ \\
\hline$(\mathrm{mm})$ & & $\ldots \ldots$ & $-\ldots-(g)-\ldots$ & 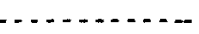 \\
\hline 1.25 & 20 & $\begin{array}{l}0.26 \pm 0.02 \\
0.26 \pm 0.02\end{array}$ & $\begin{array}{l}0.26 \pm 0.02 \\
0.26 \pm 0.02\end{array}$ & $\begin{array}{l}0.25 \pm 0.03 \\
0.26 \pm 0.02\end{array}$ \\
\hline 3.75 & 20 & $\begin{array}{l}0.93 \pm 0.09 \\
0.97 \pm 0.09\end{array}$ & $\begin{array}{l}1.24 \pm 0.11 \\
1.10 \pm 0.09\end{array}$ & $\begin{array}{l}2.22 \pm 0.20 \\
1.71 \pm 0.17\end{array}$ \\
\hline 7.5 & 20 & $\begin{array}{l}2.49 \pm 0.21 \\
2.76 \pm 0.52\end{array}$ & $\begin{array}{l}5.57 \pm 0.41 \\
6.27 \pm 0.75\end{array}$ & $\begin{array}{l}13.14 \pm 1.01 \\
15.00 \pm 1.78\end{array}$ \\
\hline 12.5 & 20 & $\begin{array}{l}5.58 \pm 0.37 \\
4.73 \pm 0.52\end{array}$ & $\begin{array}{l}20.23 \pm 1.06 \\
20.06 \pm 2.14\end{array}$ & $\begin{array}{l}57.69 \pm 2.88 \\
59.59 \pm 7.57\end{array}$ \\
\hline 17.5 & 20 & $\begin{array}{l}9.68 \pm 0.65 \\
8.42 \pm 1.24\end{array}$ & $\begin{array}{l}46.22 \pm 2.32 \\
43.86 \pm 2.65\end{array}$ & $\begin{array}{l}155.01 \pm 6.60 \\
155.62 \pm 9.91\end{array}$ \\
\hline 22.5 & 20 & $\begin{array}{l}14.59 \pm 1.03 \\
17.03 \pm 1.82\end{array}$ & $\begin{array}{r}76.86 \pm 3.52 \\
81.53 \pm 6.16\end{array}$ & $\begin{array}{l}302.95 \pm 12.60 \\
303.73 \pm 23.05\end{array}$ \\
\hline 27.5 & 10 & $\begin{array}{l}20.04 \pm 1.41 \\
15.60 \pm 2.67\end{array}$ & $\begin{array}{r}103.27 \pm 5.54 \\
96.34 \pm 9.77\end{array}$ & $\begin{array}{l}468.84 \pm 19.26 \\
466.60 \pm 24.95\end{array}$ \\
\hline 32.5 & 10 & $\begin{array}{l}25.78 \pm 1.87 \\
31.26 \pm 4.41\end{array}$ & $\begin{array}{l}121.92 \pm 8.84 \\
116.14 \pm 9.83\end{array}$ & $\begin{array}{l}615.38 \pm 31.80 \\
605.36 \pm 41.82\end{array}$ \\
\hline 37.5 & 10 & $\begin{array}{l}31.57 \pm 2.68 \\
34.68 \pm 5.28\end{array}$ & $\begin{array}{l}133.84 \pm 12.10 \\
140.28 \pm 21.17\end{array}$ & $\begin{array}{l}725.78 \pm 50.25 \\
752.13 \pm 88.15\end{array}$ \\
\hline 50.0 & 10 & $\begin{array}{l}45.06 \pm 7.20 \\
38.39 \pm 6.77\end{array}$ & $\begin{array}{l}147.35 \pm 17.25 \\
157.29 \pm 35.44\end{array}$ & $\begin{array}{r}870.85 \pm 90.69 \\
919.54 \pm 125.91\end{array}$ \\
\hline
\end{tabular}




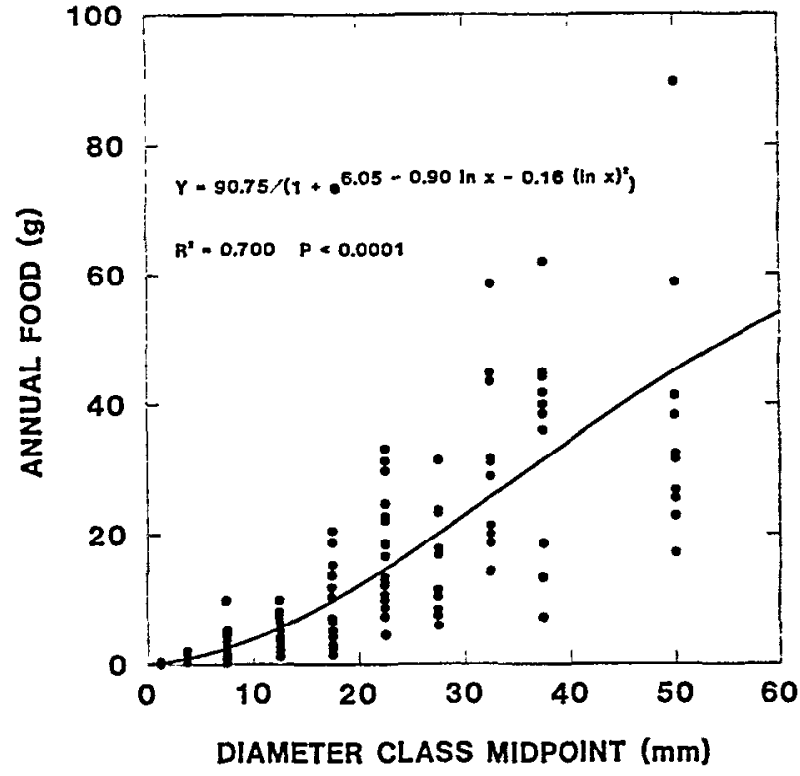

Fig. 1a.

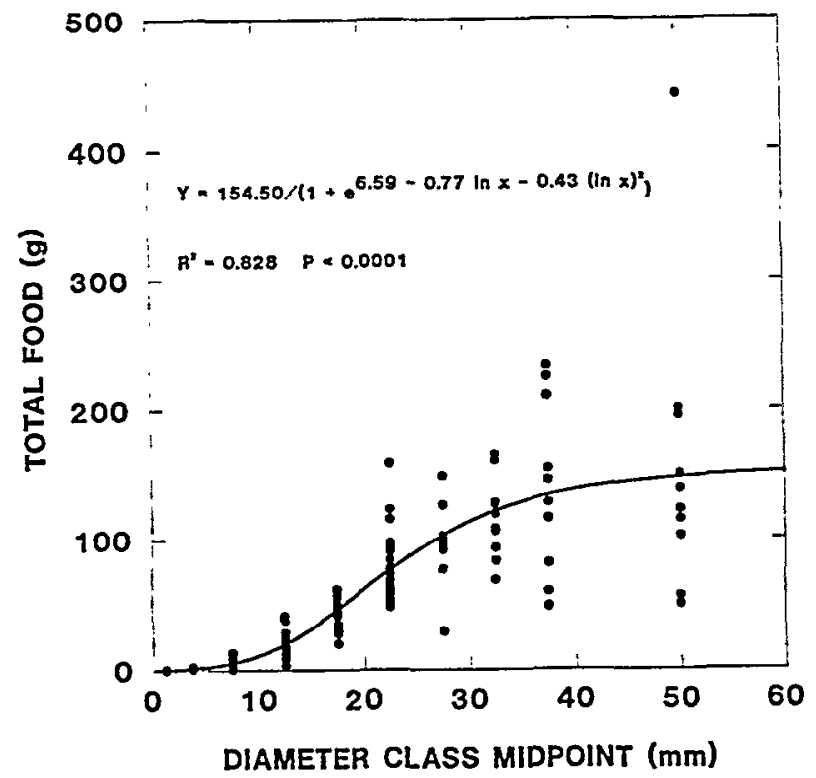

Fig. 1b.

Fig. 1a-c. Nonlinear least squares regressions of annual and total beaver food and total live biomass of coyote willow using a logistic model.

in growth form. In contrast, Fryxell and Doucets' (1991) estimates of total beaver food were similar to ours at the smaller stem diameters, but were approximately 10 times greater than ours at the larger $(60 \mathrm{~mm})$, perhaps because the proportion of biomass from leaves differed by diameter.

Our biomass estimates represent unprotected, wild plants growing in a grazed willow community. Biomass of beaver food may be affected by length of the growing season, soil-moisture rela-

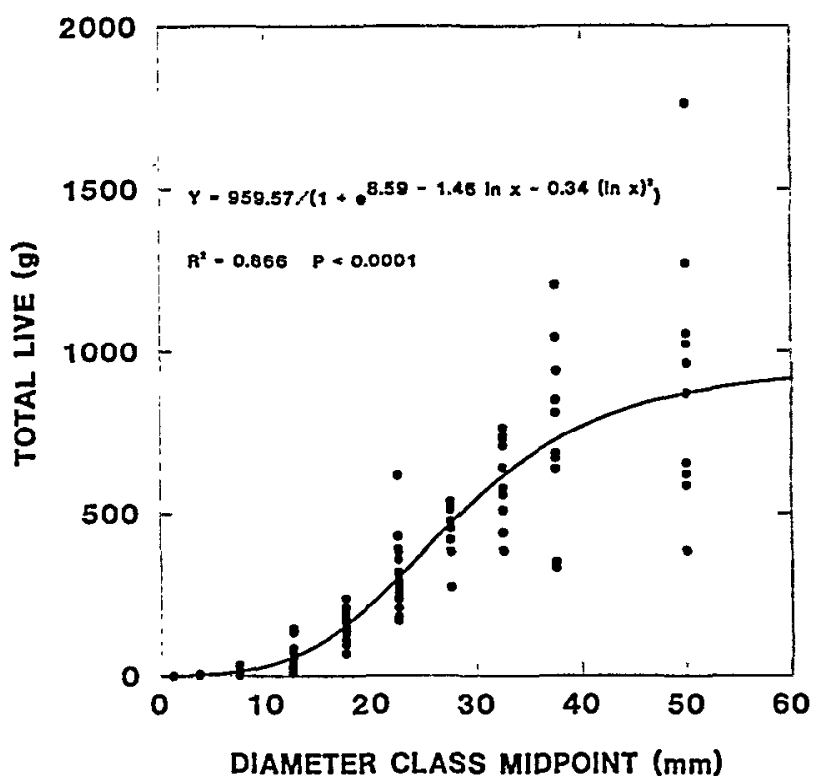

Fig. 1c. tions, competition with other plants for light and nutrients (Alaback 1986b), parasitism by insects, and utilization by beaver, livestock, and native ungulates. Repeated browsing by livestock, deer, or elk, especially in the growing season, can reduce leader production and result in a "hedged" appearance, affecting estimates of biomass. In our study, $58 \%$ of the sampled stems had some evidence of browsing by ungulates and $7 \%$ showed evidence of cutting by beaver on 1 or more leaders (note these are not synonymous with utilization rates). However, the general appearance was of a vigorous willow community with little evidence of any browsing effects.

\section{Management Implications}

Our research shows the logistic model provides reliable estimates of beaver food and total live willow biomass for a coyote willow community in Colorado. Assuming willow is limiting as winter food, managers could use these or similar data to evaluate carrying capacity or habitat suitability for beaver. For example, available beaver food $\left(\mathrm{kg} \mathrm{ha}^{-1}\right)$ could be estimated for a riparian area by multiplying the predicted biomass of beaver food (by diameter class) by the density of willow stems (by diameter class). Willow stem density could be estimated by a variety of plot or plotless sampling schemes (Bonham 1989). Carrying capacity for beavers could then be computed using estimates of annual food consumption for individual beavers or colonies. Although these data may not be available for oven-dried willow, Aldous (1938) provided some crude estimates for aspen (e.g., $232.8 \mathrm{~kg} \mathrm{yr}^{-1}$; wet, air-dried, or oven-dried not specified). Based on behavioral observations during the summer months, Belovsky (1984) estimated that beaver consumed $551 \mathrm{~g}$ dry weight day ${ }^{-1}$ of hardwood leaves, bark, and twigs, as well as, $69.0 \mathrm{~g} \mathrm{day}^{-1}$ of 
Table 3. Means and standard errors 1 for coyote willow variables using the sample data by stem diameter class.

\begin{tabular}{lcccc}
\hline $\begin{array}{l}\text { Diameter } \\
\text { class } \\
\text { midpoint }\end{array}$ & $\mathrm{n}$ & Age & $\begin{array}{l}\text { Total } \\
\text { food }\end{array}$ & Dead \\
\hline (mm) & & $(\mathrm{yrs})$ & $(\%)$ & $(\%)$ \\
& & & & \\
1.25 & 20 & $1.0 \pm 0.0$ & $93.6 \pm 3.2$ & $6.4 \pm 3.2$ \\
3.75 & 20 & $1.3 \pm 0.1$ & $65.8 \pm 3.2$ & $3.2 \pm 1.2$ \\
7.50 & 20 & $2.3 \pm 0.2$ & $41.0 \pm 1.7$ & $5.5 \pm 1.2$ \\
12.5 & 20 & $3.8 \pm 0.3$ & $31.9 \pm 2.0$ & $12.6 \pm 3.9$ \\
17.5 & 20 & $5.2 \pm 0.3$ & $25.5 \pm 1.2$ & $11.5 \pm 1.4$ \\
22.5 & 20 & $5.6 \pm 0.2$ & $24.8 \pm 0.8$ & $8.2 \pm 1.4$ \\
27.5 & 10 & $6.2 \pm 0.2$ & $18.8 \pm 1.9$ & $13.7 \pm 4.4$ \\
32.5 & 10 & $6.7 \pm 0.4$ & $16.4 \pm 1.4$ & $15.6 \pm 4.4$ \\
37.5 & 10 & $6.4 \pm 0.2$ & $14.8 \pm 1.8$ & $20.5 \pm 5.4$ \\
50.0 & 10 & $8.2 \pm 0.7$ & $12.2 \pm 1.8$ & $27.8 \pm 5.9$ \\
\hline
\end{tabular}

${ }^{1}$ Degrees of freedom equals $n-1$.

2 Percent of total stem weight that was beaver food.

3 Percent of total stem weight that was dead.

herbaceous aquatic plants. In addition, willow might also be important to beaver for reasons other than providing food (i.e., dam-building material) and factors other than willow availability might also limit carrying capacity of beaver. Because we did not replicate samples across the geographical range of coyote willow, statistical inference to other areas is not appropriate and biological inference should be judicious.

\section{Literature Cited}

Alaback, P.B. 1986a. Biomass regression equations for understory plants in coastal Alaska: effects of species and sampling design on estimates. Northwest Sci. 60:90-103.

Alaback, P.B. 1986b. Biomass-dimension relationships of understory vegetation in relation to site and stand age, $\mathrm{p}_{n}$ 141-148. In: E. H. Wharton and T. Cunia (eds.). Estimating tree biomass regressions and their error. USDA For. Serv. Gen. Tech. Rep. NE-GTR-117.

Aldous, S.E. 1938. Beaver food utilization studies. J. Wildl. Manage. 2:215222.

Allen, A.W. 1983. Habitat suitability index models: beaver. U.S. Fish Wildl. Serv. FWS/OBS-82/10.30 Revised.

Apple, L.L., B.H. Smith, J.D. Dunder, and B.W. Baker. 1985. The use of beavers for riparian/aquatic habitat restoration of cold desert, gully-cut stream systems in southwestern Wyoming, p. 123-130. In: G. Pilleri (ed.), Investigations on beavers, Vol. IV., Brain Anatomy Institute, Berne, Switzerland.

Baker, B.W., D.L. Hawksworth, and J.G. Graham. 1992. Wildlife habitat response to riparian restoration on the Douglas Creek watershed, p. 62-80. In: C. Zimmerman (ed.), Proc. Fourth Annu. Conv. Colo. Riparian Assoc., Steamboat Springs, Colo.

Bates, D.M., and D.G.Watts. 1988. Nonlinear regression analysis and its applications. John Wiley and Sons, Inc., New York, N. Y.

Belovsky, G.E. 1984. Summer diet optimization by beaver. Amer. Midland Natur. 111:209-222.

Bonham, C.D. 1989. Mleasurements for terrestrial vegetation. John Wiley and Sons. Inc., New York. N.Y.

Brown, J.K. 1976. Estimating shrub biomass from basal stem diameters. Can. J. For. Res. 6:154-158.

Brunsfeld, S.J., D.E. Soltis, and P.S. Soltis. 1991. Patterns of genetic variation in Salix section Longifoliae (Salicaceae). Amer. J. Bot. 78:855-869.

Conroy, S.D., and T.J. Svejcar. 1991. Willow planting success as influenced by site factors and cattle grazing in northeastern California. J. Range Manage. 44:59-63.

Dorn, R.D. 1977. Willows of the Rocky Mountain states. Rhodora 79:390429.
Fryxell, J.M., and C.M. Doucet. 1991. Provisioning time and central-place foraging in beavers. Can. J. Zoology 69:1308-1313.

Hall, J.G. 1960. Willow and aspen in the ecology of beaver on Sagehen Creek, California. Ecology 41:484-494.

Kindschy, R.R. 1989. Regrowth of willow following simulated beaver cutting. Wildl. Soc. Bull. 17:290-294.

MacCracken, J.G., and V. Van Ballenberghe. 1993. Mass-diameter regressions for moose browse on the Copper River Delta, Alaska. J. Range Manage. 46:302-308.

MacDonald, D. 1956. Beaver carrying capacity of certain mountain streams in North Park, Colorado. M.S. Thesis, Colo. State Univ., Fort Collins, Colo.

Marshall, P.L., M.D. Pitt, and H.L. Habgood. 1990. Estimating browse biomass using multiple regression and plotless density estimates. J. Wildl. Manage. 54:180-186.

McClure, J. P., and R. L. Czaplewski. 1987. High order regression models for regional volume equations, p. 295-303. $I n$ : E. H. Wharton and T. Cunia (eds.), Estimating tree biomass regressions and their error. USDA For. Serv. Gen. Tech. Rep. NE-GTR-117.

Naiman, R.J., C.A. Johnston, and J.C. Kelley. 1988. Alteration of North American steams by beaver. Bioscience 38:753-762.

O'Brien, D.F. 1938. A qualitative and quantitative food habit study of beavers in Maine. M.S. Thesis, Univ. Maine, Orono, Maine.

Oldemeyer, J.L. 1982. Estimating production of paper birch and utilization by browsers. Can. J. For. Res. 12:52-57.

Parresol, B. R. 1993. Modeling multiplicative error variance: an example predicting tree diameter from stump dimensions in baldcypress. For. Sci. 39:670-679.

Pearson, D.C. 1977. Population and natural history studies of beavers (Castor canadensis) on Las Flores Ranch, Summit Valley, California. M.S. Thesis, Cal. State Polytechnic Univ., Pomona, Cal.

Roundy, B.A., G.B. Ruyle, and J. Ard. 1989. Estimating production and utilization of jojoba. J. Range Manage. 42:75-78.

Ruyle, G.B., J.E. Bowns, and A.F. Schlundt. 1983. Estimating snowberry (Symphoricarpos oreophilus) utilization by sheep from diameter-weight relations. J. Range Manage. 36:472-474.

Sakamoto, Y., M. Ishiguro, and G. Kitagawa. 1986. Akaike information criterion statistics. K T K Scientific Publishers, Tokyo, Japan.

SAS Institute Inc. 1987. SAS/STAT guide for personal computers, ver. 6 ed. SAS Inst. Inc., Cary, N.C.

Shepperd, W.D., and F.W. Smith. 1993. The role of near-surface lateral roots in the life cycle of aspen in the central Rocky Mountains. For. Ecol. Manage. 61:157-170.

Telfer, E.S. 1969. Twig-weight diameter relationships for browse species. J. Wildl. Manage. 33:917-921.

Vories, K.C. 1974. A vegetation inventory and analysis of the Piceance Basin and adjacent drainages. M.S. Thesis, Western State College of Colo., Gunnison, Colo.

Wilkinson, L. 1990. SYSTAT: the system for statistics. SYSTAT, Inc., Evanston, Ill. 